\title{
Review on Traditional Processing of Fermented Datta (Qotchqotcha) in Ethiopia
}

\author{
Bikila Fikadu Gemechu \\ Department of Food Process Engineering, Gambella University, Gambella, Ethiopia
}

\section{Email address:}

biki2723@gmail.com

\section{To cite this article:}

Bikila Fikadu Gemechu. Review on Traditional Processing of Fermented Datta (Qotchqotcha) in Ethiopia. American Journal of Engineering and Technology Management. Vol. 6, No. 4, 2021, pp. 72-75. doi: 10.11648/j.ajetm.20210604.12

Received: June 23, 2021; Accepted: August 4, 2021; Published: August 18, 2021

\begin{abstract}
The aim of this review paper was to reviewed the traditional fermented datta (qotqotcha) in Ethiopia. Datta is one of the among traditional food found in Ethiopia. It consumed with other items due to enhance the desirable aromas and flavors. The Spiced chili paste (Datta) is a traditional food in the southern part of Ethiopia, consumed mainly with raw meat and known to improve appetite. The ingredient of datta is green pepper, fresh sweet basil, garlic, ginger, seeds of rue. The main ingredient of datta is small chili pepper at it is green stage. Fermented foods and beverages, whether of plant or animal origin, play an important role in the diet of people in many parts of the world. Fermented foods not only provide important sources of nutrients but have also great potential in maintaining health and preventing diseases. Lactic acid bacteria and yeasts are the major group of microorganisms associated with traditional fermented foods. The mixing of vegetable-spice can be result of microbial fermentation. Fermentation is biological process, which has the potential to improve the nutrient availability in foods, and the breakdown of some sugars and starches makes for easy digestibility of fermented foods and increase in the availability of vitamins and minerals.
\end{abstract}

Keywords: Fermented Datta, Traditional, Pepper, Ingredients

\section{Introduction}

Peppers are the oldest and most important carotenoids [1], which widely used as food colorants [2] Pepper is native to southern part of North America and northern South America [3]. Traditional product, "datta", is among the traditionally fermented condiments in Ethiopia and consumed with other food items because of its pleasing aromas and flavors that develop during fermentation. This condiment results from the microbial fermentations of vegetable-spice mixtures [4]. Fermentation found to be useful in flavoring foods, in inhibiting spoilage bacteria and pathogens, in intestinal health and other health benefits related to blood cholesterol levels, immune competence and antibiotics production. Inexpensive and often little or no heat is required during the process thus making it fuel efficient [5]. The traditional development of foods and beverages are often a small scale and household basis, and use of simple local available equipments. The traditional processing of foods are cost effective and low energy processing. Datta (qotchqotcha in oromiffa) is a condiment mainly in the southern part of the
Ethiopia. Traditionally fermented datta is used for roasted meat and other traditional meals (milk products).

\section{Ingredient of Datta and Fermentation Process}

The major ingredient in the making of datta is the small chili pepper at its green stage. The green pepper, together with the seeds, is thoroughly washed and cut into pieces. Garlic and ginger, in small proportions, are peeled, washed and cut into small pieces. The pepper, garlic and ginger are mixed with small amounts of fresh sweet basil and seeds of rue. The mixed ingredients are manually wet-milled on a flat traditional stone-mill into a greenish paste. This is transferred into a container, tightly closed and left to ferment at ambient temperatures [4].

The pre-processing of "datta" ingredients was performed following the traditional methods. 
The fruits of hot peppers were washed thoroughly with clean tap water and exposed for sun dried. The dried fruits were gently cut in to pieces manually and crushed or wet20 green and red datta separately to avoid crosscontamination. During grinding, fine powdery paste was checked with finger tips and then different Ethiopian spices mainly Aframomum anguistifolium, table salt, coriander, white cumin, and moreover, garlic was peeled, and washed. The experiments with spices using red and green pepper were done by adding pre-weighted different spices into plastic container, and mixed and ground together with pepper that conceded first round grinding until uniform composition and fine paste of datta was produced [6].

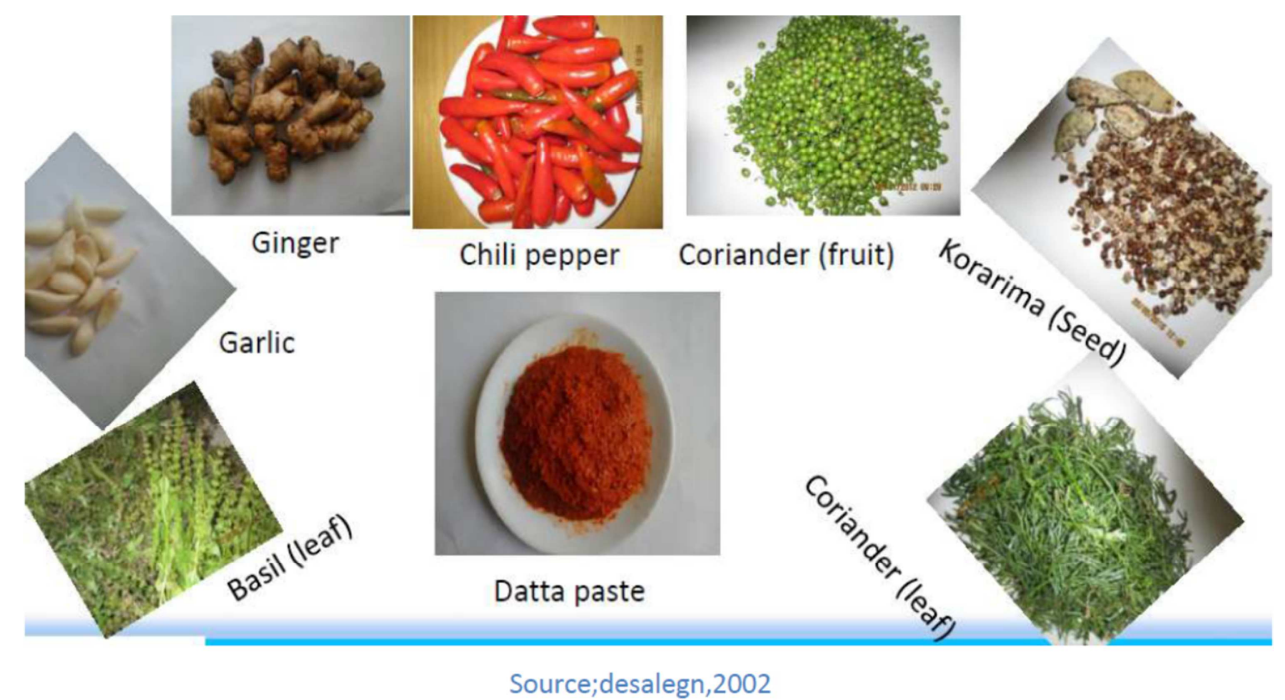

Figure 1. Ingredients of data.

\subsection{Datta Fermentation}

In datta fermentation, the count of aerobic mesophilic bacteria remained unchanged during the fermentation [4]. Lactic acid bacteria initiated the fermentation at a level of $10 \mathrm{cfu} / \mathrm{g}$ and reached $109 \mathrm{cfu} / \mathrm{g}$ at end of fermentation on day 7. Contrary to awaze fermentation, the homo fermentative lactic acid bacteria initiated and dominated datta fermentation for the first two days. The heterolactics dominated thereafter. Challenge studies on datta fermentation with Salmonella typhimurium ([4] and E. coli O157:H7 [7] showed that the fermenting condiments had strong bactericidal property against the test strains. The fermenting product, when stored at ambient temperature, also had a fast inhibitory property against $E$. coli O157:H7, although the pathogen survived for more than seven days at refrigeration storage [7].

Table 1. Fermentation time and ph of datta and awaze.

\begin{tabular}{|c|c|c|c|c|c|c|}
\hline \multirow{2}{*}{ time } & \multicolumn{3}{|c|}{ Awaze } & \multicolumn{3}{|c|}{ Datta } \\
\hline & PH & homofermentative & heterofermentative & PH & homofermentative & heterofermentative \\
\hline 0 & 5.6 & $<4$ & 6 & 5.56 & 4.85 & $<3$ \\
\hline 24 & 5.3 & $<5$ & 7.43 & 5.18 & 6.5 & $<5$ \\
\hline 48 & 4.5 & $<7$ & 9.11 & 4.93 & $<5$ & 7.91 \\
\hline 72 & 4.43 & 9.14 & 9.5 & 4.71 & $<5$ & 7.78 \\
\hline 96 & 4.36 & 9.0 & $<5$ & 4.69 & $<5$ & 7.83 \\
\hline 120 & 4.31 & 9.14 & $<5$ & 4.63 & $<5$ & 9.11 \\
\hline 144 & 4.09 & 8.74 & $<5$ & 4.61 & $<5$ & 8.93 \\
\hline 168 & 3.94 & 8.69 & $<5$ & 4.61 & $<5$ & 9.03 \\
\hline 192 & 3.92 & 8.85 & $<5$ & End & End & End \\
\hline 216 & 3.86 & 8.49 & $<5$ & & & \\
\hline 241 & 3.86 & 8.56 & $<5$ & & & \\
\hline 264 & 3.82 & 8.53 & $<5$ & & & \\
\hline 288 & 3.78 & 8.99 & $<5$ & & & \\
\hline
\end{tabular}

Source (Ahmed et al., 2001).

\subsection{Safety of the Fermented Product (Shelf Stability and Spoilage of Datta)}

There are many traditional condiments in different parts of the world produced by microbial fermentations. Such traditional condiments are used as taste enhancers in many traditional dishes. The majority of these fermentations are accompanied by certain biochemical changes of nutritional importance [8]. Probiotic lactic acid bacteria (LAB) are known to inhibit the growth of food-borne pathogenic 
microorganisms such as Escherichia coli, Salmonella typhi, Salmonella typhimurium and Staphylococcus aureus [9-11], Pseudomonas aeruginosa, Bacillus cereus, Klebsiellapneumoniae, Proteus spp., Corynebacterium spp., and Streptococcus pneumoniae [12].

Several studies demonstrated the inhibitory effect of LAB, isolated from various Ethiopian traditional fermented foods, condiments and alcoholic beverages against some foodborne pathogens $[13,14,11]$ and they also evaluated the in-vitro $[13,14]$ and in-vivo [9] probiotic properties of lactic acid bacteria. The behavior of E. coli $\mathrm{O} 157: \mathrm{H} 7$ in fermenting and cold stored Datta and Awaze was also reported by [7] However there are still few research data available on the probiotic properties of LAB from condiments. Most of the traditional fermented products of Ethiopia are consumed withoutfurther heat processing. Thus they are ideal vehicles to carry probiotic bacteria into the human gastrointestinal tract.

\subsection{Importance of Pepper}

Pepper is a very important commercial crop, cultivated for vegetable, spice, and value-added processed products [15]. Besides vitamins $\mathrm{A}$ and $\mathrm{C}$, the fruits contain mixtures of antioxidants particularly carotenoids, ascorbic acid, flavonoids and polyphenols [16]. This makes it a very important constituent of many foods, adding flavor, color and pungency and, hence, an important source of nutrition for humans. Peppers can be used whole, chopped or in various processed forms such as fresh, dried and ground into powder (with or without the seeds), or as an extract. In most highly developed countries, the fresh fruits can be processed into paste and bottled for sale in supermarkets. In Ethiopia, the pepper product, "datta" is widely used by almost all over the country but it is dominant in the southern part of the country. Pepper can also be used medically for the treatment of fevers and colds [17] Bell pepper, being a very rich source of vitamins $\mathrm{A}, \mathrm{C}, \mathrm{B} 6$, folic acid and beta-carotene, provides excellent nutrition for humans [16].

Antioxidant compounds present in the different colors (green, yellow, orange, and red) in sweet bell peppers give them an antioxidative potential which helps protect the body from oxidative damage induced by free radicals when consumed [18]. It reduces the risk of cardiovascular diseases, asthma, sore throat, headache and diabetes. Red pepper on the other hand contains lycopene, which is believed to possess anti-cancer properties [18]. The traditional fermentation techniques are often a small scale and household basis, characterized by the use of simple nonsterile equipment, chance or natural inoculums, unregulated conditions, sensory fluctuations, poor durability and unattractive packing of the processed products resulting in food of unpredictable quality [19]. With increasing industrialization and urbanization, efforts are presently geared towards the development of large-scale factory production facilities for local foods where the quality of the finished product will be assured [20]. Because fermented foods can offer with numerous of benefits: such as; supplementing food, reduction of mortality rate, market improvement, poverty alleviation, food availability, food security and etc. To date, the production of fermented vegetables including pepper and pepper product usually made by spontaneous fermentation with various naturally bacteria present on the raw materials [21].

\subsection{Chemical and Phytochemical Composition of Pepper}

Pepper cultivars are characterized by great diversity of fruit morphological characteristics and nutrient composition. Fruit color changes during ripening, and can become white, yellow, orange, red, violet, and even chocolate-brown in a stage of harvest maturity $[18,22]$. Pepper can be used raw and processed into various kinds of products, so it is valuable material for frozen and processing industry. Pepper is an important agricultural crop, not only because of its economic importance, but also due to nutritional and medicinal value. It is the excellent source of natural colors and antioxidant compounds [23]. A wide spectrum of antioxidant vitamins, carotenoids, and phenolic compounds are present in pepper. The intake of these compounds in food is an important health-protecting factor by prevention of wide spread human diseases. As consumption continues to increase, red peppers could provide important amounts of nutritional antioxidants to the human diet [24].

Pepper contains many chemicals, including water, fixed (fatty) oils, steam-volatile oil, carotenoids, capsaicinoides, resin, protein, fiber and mineral elements. Many of these chemicals have importance for nutritional value, taste, colour and aroma. The two most important groups of chemicals found in chilli are the carotenoids and capsaicinoids [25]. Fruits and vegetables are a major source of both "macro" nutrients such as fiber and carbohydrates, and "micro" nutrients such as Vitamin C, B complex (thiamin, riboflavin, B6, niacin, folate), A, E, minerals, and the lesser-studied polyphenolics, carotenoids, and glucosinolates. Nutrients may be classified as either water or lipid soluble, meaning they dissolve in water or a lipid medium. Water-soluble nutrients include Vitamin C, B complex, polyphenolics, and glucosinolates. Fat-soluble nutrients include Vitamin A, E, and other carotenoids such as lycopene and $\beta$-carotene. Vitamin $\mathrm{C}$ is one of the most sensitive vitamins, being degraded relatively quickly by exposure to heat, light, and oxygen. The nutritional value of hot pepper needs special attention not only its pungency or color, it is a rich source of vitamin. Both the hot and sweet peppers contain more vitamin C [26].

\section{Conclusion}

Datta is fairly a low-energy requiring for processing. In cases fermentation of traditional foods and beverages are important to obtain a certain food, the microorganisms present on the raw ingredients or in the containers spontaneously take care of the process. In most of these products the fermentation is spontaneous and involves different microorganisms. Generally, clear understanding of 
the procedures involved in the process of making of the traditional fermented food and beverage products could help to design mechanism for production of an industrially based finished product so as to develop the keeping quality of the products. and it has the advantage of reducing wastage during processing, which is significant at household level. In line with this, eating fermented foods has a beneficial health effect for human beings as well as animals.

\section{References}

[1] Jozsef, D., Zoltan, M. and Gyula T. (1996). Carotenoid Composition in the Fruits of Capsicum annum. Journal of Agricultural and Food Chemistry, 44: 711-716.

[2] Matsufuji Hoshi, Nakamura Hiromichi, Chino Makoto and Takeda Mitsuharu. (1998) Antioxidant Activity of Capsanthin and Fatty Acid Ester in Paprika (capsicum annum). Journal of Agriculture and Food Chemistry, 46: 3468-3472.

[3] Grubben, G. J. H. and Tahir, I. M. El. (2004). Capsicum annuumL. in PROTA 2: Vegetables/Legumes, (Grubben, G. J. H. and Denton, O. A. Eds.), PROTA Foundation, Wageningen, The Netherlands.

[4] Idris A., Mehari T. and Ashenafi M. (2001). Some microbiological and biochemical studies on the fermentation of 'awaze' and 'datta', traditional Ethiopian condiments, International Journal of Food Sciences and Nutrition, 52: 1, $5-14$.

[5] Shimelis and Rakshit. (2008). Influence of natural and controlled fermentations ongalactosides, antinutrients and protein digestibility of beans (Phaseolus vulgaris L.) International Journal of Food Science and Technology .43, $658-665$.

[6] Dawit, (2018) Product development and Evaluation of Fermented hot pepper (Capsicum annuum L.), Datta.

[7] Tsgaye, M., Ephraim, E. and Ashenafi, M. 2004. Behaviour of Escherichia coli O157:H7 during the fermentation of Datta and Awaze, traditional Ethiopian fermented condiments, and during product storage at ambient and refrigeration temperatures. Food Microbiology 21: 743-751.

[8] Hesseltine CW, Wang WL (1980). The importance of traditional fermented foods. BioScience 30: 402-404.

[9] Tadesse, G., Ephraim, E. and Ashenafi, M. 2005. Assesment of the antimicrobial activity of lactic acid bacteria isolated from Borde and Shameta, traditional Ethiopian fermented beverages, on some foodborne pathogens and effect of growth medium on the inhibitory activity. Internet Journal of Food Safety 5: 13-20.

[10] Klayraung, S., Viernstein, H., Sirithunyalug, J. and Okonogi, S. 2008. Probiotic properties of lactobacilli isolated from thai traditional food. Scientia Pharmaceutica 76: 485-503.

[11] Tesfaye, A., Mehari, T. and Ashenafi, M. 2011. Evaluation of the in vitro and in vivo probiotic qualities of Lactic Acid Bacteria (LAB) recovered from locally fermented products. International Journal of Probiotics and Prebiotics 6: 1-8.

[12] Al-Allaf, M., Al-Rawi, A. and Al-Mola, A. 2009.
Antimicrobial activity of lactic acid bacteria isolated from minced beef meat against some pathogenic bacteria. Iraqi Journal of Veterinary Science 23: 115- 117.

[13] Bacha, K., Mehari, T. and Ashenafi, M. 2009. In vitro probiotic potential of some Lactic Acid Bacteria (LAB) isolated from Wakalim, a traditional Ethiopian fermented beef sausage. Ethiopian Journal of Health Sciences 19: 21-27.

[14] Dessalegn, A. and Ashenafi, M. 2010. Evaluation of the Probiotic Properties and Antibiotic Resistance of Lactic Acid Bacteria Isolated from Awaze, Qotchqotch and Teff dough, traditional Ethiopian fermented foods. Internet Journal of Food Safety 12: 187-191.

[15] Kumar, S. and Rai, M. (2005). Chile in India. Chile Pepper Institute Newsletter (XXII), pp. 1-3 Latta and Eskin (1980). Determination of Phytate. Journal of Cereal chemistry.

[16] Nadeem, M., Muhammad, F., Anjum, Khan, A. M. R., Saed, M. and Riaz, A (2011). Antioxidant Potential of Bell Pepper (Capsicum annum L.). Pakistan Journal of Food Science, 21 (14): 45-51.

[17] Norman, J. C. (1992). Tropical vegetable crops. Pp. 78-87.

[18] Simonne, A. H., Simonne, E. H., Eitenmiller, R. R., Mills, H. A. and Green, N. R. (1997). Ascorbic acid and provitamin A contents in unusually colored bell peppers (Capsicumannuum L.). Journal of Food Composition Analysis, 10 (4), 299-311.

[19] Olanrewaju OO., Victor OO. and Titilayo TA. (2009). Safety of Small-Scale Food Fermentations in Developing Countries. Internet Journal of Food Safety 11 (2009): 29-34. Oladele A. K. and Aina J. O. (2007). Chemical composition and functional properties of flour.

[20] Agarry OO., Nkama I. and Akoma O. (2010). Production of Kunun-zaki (A Nigerian fermented cereal beverage) using starter culture. International Research Journal of Microbiology 1 (2): 18-25.

[21] Tanganurat, W., Quinquis, B., Leelawatcharamas, V. and Bolotin, A. (2009). Genotypic and phenotypic characterization of Lactobacillus plantarum strains isolated from Thai fermented fruits and vegetables. Journal of Basic Microbiology, 49, 377-385.

[22] Valšíková, M., Kralova, J. and Barkoci, S. (2006). Study of some characteristics of vegetable pepper varieties. Horticultural Science. (Prague), 33 (4), 153-157.

[23] Howard, L. R., Talcott, S. T., Brenes, C. H., and Villalon, B. (2000). Changes in phytochemical and antioxidant activity of selected pepper cultivars (Capsicum spp.) as influenced by maturity. Journal of Agriculture and Food Chemistry, 48, 1713-1720.

[24] Martinez S, Lopez M, Gonzalez-Raurich M, Alvarez AB. (2005). The effects of ripening stage and processing systems.

[25] Bosland, P. W. and Votava, E. J. (2000). Peppers: Vegetable and Spice Capsicums. CAB International, Wallingford, UK Latham, E. (2009). The colorful world of chillies.Stuff.co.nz.

[26] Rehima, Mussema (2006). Analysis of Red Pepper Marketing. The case of Alaba and Siltie in SNNPRS of Ethiopia. A Thesis submitted to Department of Agricultural Economics School of Graduate studies Haramaya University. 